\title{
The Impact of Board Gender and Multiple Directorship on Cash Holdings: Evidence from Jordan
}

\author{
Mohammad Yousef Alghadi", Ahmad Rizal Mazlan, Adilah Azhari \\ School of Economic Finance and Banking, University Utara Malaysia, Sintok, Malaysia \\ Email address: \\ Mohammad.algadi@yahoo.com (M. Y. Alghadi) \\ ${ }^{*}$ Corresponding author \\ To cite this article: \\ Mohammad Yousef Alghadi, Ahmad Rizal Mazlan, Adilah Azhari. The Impact of Board Gender and Multiple Directorship on Cash \\ Holdings: Evidence from Jordan. International Journal of Finance and Banking Research. Vol. 5, No. 4, 2019, pp. 71-75. \\ doi: $10.11648 /$ j.jifbr.20190504.12
}

Received: April 11, 2019; Accepted: June 14, 2019; Published: August 6, 2019

\begin{abstract}
This study examined the influence of corporate governance on company cash holding by explaining the relationship between board gender, multiple directorship and cash holding using a sample of 87 non-financial companies including industrial and service companies that listed on the Amman Stock Exchange from 2011 to 2017. By using Ordinary Last Square regression model (OLS). The findings indicate that board gender, multiple directorship positively influence cash holdings, supporting the agency theory. The findings of this study contribute to the formulation of better corporate governance policies that can help improve corporate cash holdings. This study has several empirical implications for policy makers in Jordan; it is important for policy makers to improve the role of the board of directors in monitoring the firm. One possible way of doing so is to encourage firms in Jordan to employ female that can provide better monitoring services and also firms can benefit from their experiences. In addition, these rules and regulations need to be activated by the policy makers to ensure that firms comply with their requirements. Moreover, developing countries are in need of providing better compliance with international governance standards. This can be done by adopting good governance practices, improving shareholder rights and activating laws and regulations that govern firms' performance.
\end{abstract}

Keywords: Agency Cost, Corporate Governance, Cash Holdings, Board Gender, Multiple Directorship, Jordan Stock Market

\section{Introduction}

Generally, firms hold significant proportion of cash in their total assets. For example, the average cash ratio in the US is $23.2 \%$ [1], 9.9\% in the UK [2], 9.1\% in Turkey [3] and $8 \%$ in Spain [4]. Since practically all firms hold cash more than their normal requirements, it makes sense to understand the firms' motivations for holding cash [5].

In many emerging markets, firms hold enormous cash balances to be used during bad economic conditions. Holding cash enables firms to carry out valuable investments [6] and provides safety cushion in both normal and bad economic conditions [7]. Theoretically, firms can survive without cash reserves in an ideal world with perfect markets. However, the real-life imperfections in the markets require the firms to maintain a buffer to cover the cash deficits due to the operating needs of the firm. [8] argues that cash holding plays a significant role in the economic growth of emerging markets, while according to [9], cash is a readily available investment for a firm. In addition, [10] stressed that firms must hold cash to ensure the timing of cash movements and overall positive cash flow.

Low cash holding is alarming for firms in terms of their inability to survive in bank credit tightening or financial crisis periods [7]. Global working capital statistics highlighted the need of cash in the Middle East and North Africa (MENA) region to support innovation and stimulate growth [11]. Similarly, despite of high profitability indicators, Jordanian nonfinancial firms are facing liquidity deficit by holding lower amount of cash $[12,13]$. Decreased cash holding is alarming for firms in terms of their inability to survive in bank credit tightening or financial crisis periods [7]. 
Corporate governance plays an important role in controlling the management of working capital components by formulating sound policies [10]. [14, 15] argued that cash holdings decline when self-interested managers spend excess cash. Firms with weak corporate governance mechanisms hold lower cash as a result of decisions by managers to spend cash reserves quickly despite the fact that such accumulating cash may provide future flexibility. It provides an implication that firms with weak corporate governance practices are more likely to hold lower cash than firms with strong governance.

Developing countries are in need of providing better compliance with international governance standards. Similarly, In Jordan, [16] assessed that companies do not follow the Jordanian corporate governance regulations which requires attention of policy makers to motivate companies to apply corporate governance principles. [17] argued that weak corporate governance is the main cause for higher bankruptcy cases in Jordan. A corporate governance assessment, undertaken by the European Bank of Reconstruction and Development (EBRD) for Jordan in year 2016[18], revealed the "low compliance" of Jordanian corporate governance framework.

\section{Literature Review and Hypotheses Development}

Many previous study have sought about the relationship between corporate governance and cash holding. Mostly studies nominated the most significant characteristics of corporate governance for this relationship included: (i) board gender; and (ii) Multiple directorships. Below as a brief overview of these characteristics

Gender diversity in the top management increases independence and improves decision making process [19]. Board gender is considered a key factor contributing to the quality of corporate governance where several corporate governance codes in developed countries emphasized the importance of gender diversity to avoid the problems arising from like-minded individuals and thus enhance the effectiveness of the boards.

Board gender diversity provides corporations with positive outcomes since diversity generates greater variety of perspectives and this increase the likelihood of creative and innovations in the board which reflects positively the effectiveness of the board and its decisions [20]. According to several authors [21-24], there is a difference between men and women where women are more risk averse than men as well women will adopt less aggressive strategy choice and will invest in more sustainable projects than men. [24] indicated that gender diversity affects corporation decision making in particular the presence of women either in board of directors or in management positions affects the corporate governance and the corporate policy. Likewise, [20] suggested that board diversity either gender or racial is considered an important factor contributing to good corporate governance.
Prior literature shows that gender diversity influences corporate decision making. It has been shown that the concentration of women in either the board of directors or management influences corporate governance as well as corporate policy. On the one hand, female directors influence the effectiveness of the functioning of corporate boards in general [25] or the quality of monitoring [26]. On the other hand, female executives seem more risk averse when making strategic and financial decisions [22, 23]. However, empirical evidence on whether these differences in governance and corporate policy affect corporate performance is mixed.

In several countries, corporate governance codes have established the significance of board diversity. The UK corporate governance code (2016) stated that "The problems arising from "groupthink" have been exposed in particular as a result of the financial crisis. One of the ways in which constructive debate can be encouraged is through having sufficient diversity on the board. This includes, but is not limited to, gender and race";

However, in less developed countries (such as Jordan) less attention has been paid to the issue of board gender. So far, the existing legislations in Jordan and the corporate governance code issued by Jordan Securities Commission (JSC) have not yet taken any step towards the issue of board gender diversity. Despite that the International Finance Corporation (IFC) in 2014 recommended developing and emerging markets including Jordan to encourage board diversity by promoting women's leadership; providing and sharing arguments on the benefits of board diversity; and starting a policy-level dialogue aimed at increasing the number of women on boards.

Cash is a flexible asset, it allows for managerial discretionary spending and perquisite consumption [27-31, 15]. Hence, if gender diversity influences managerial behaviour, it is likely to be reflected in the cash policy decisions made by managers. Managerial discretionary spending and perquisite consumption $[29,31,15]$. Hence, if gender diversity influences managerial behavior, it is likely to be reflected in the cash policy decisions made by managers. [32] investigated the influence of board gender on cash holdings for the 2563 firms from 14 European countries. The fixed effect regression resulted in significant and positive relationship between board gender and cash holdings. [32] considered 81 French firms over the period of 2006-2014 and found that board gender is positive but insignificant with cash holdings.

H1: Board gender is positively related to cash holdings.

Multiple directorships is a phenomenon whereby an individual holds two or more firms [33]. Multiple directorships allow executives to develop their expertise and learning about diverse strategies and styles of management $[34,35]$, and build-up a professional network. Directors with multiple board seats may have advantage in accessing funds [36], use their external contacts for reputational purposes [37], to open new markets.

The corporate governance consequences of multiple directorships have attracted the attention of both practitioners 
and researchers. Many professional bodies, such as the National Association of Corporate Directors (1996) and the Council of Institutional Investors (2003), have expressed concern that directors who hold multiple directorships are incapable of adequately monitoring management and have proposed limiting the number of outside board seats held by individuals. Some researchers such as, [38, 39], by contrast, favor multiple directorships and argue that multiple directorships leads to the growth of directors' expertise and experience. In other words, the busier a director is, the more skillful and competent he or she is.

Despite much research on the topic [40-42], multiple directorships influence firms' financial policy, is not clear and needs investigation. The most part of literature focused on the relationship of cash holdings decisions on firm value. [43] find that bidding firms whose directors hold more directorships experience more negative abnormal returns at acquisition announcements. In contrast, [44] found that the presence outside director in board structure helps to improve the board decision making and overall enhances firm performance.

Jiraporn, P., Singh, M., and Lee, C. I. argue that the more a director is involved in other duties, the greater the director's risk of missing board meetings due to over commitment which may negatively affect the firms' cash holdings [45]. Based on this view, the extent of board busyness can be associated negatively with cash holdings as a signal that busy members on the board provide firms with valuable assistance, thus preventing the misuse of cash resources. [46] argued that $46 \%$ of Jordanian firms have multiple directorships. However, to the best knowledge of this study, there are few studies on the relationship between multiple directorship and cash holdings. In contrast, [33] reported significant and positive result.

H2: Multiple directorship is positively related to cash holdings.

\section{Methodology}

The data for this study is collected from annual reports of 87 non-financial companies listed on the Jordanian Stock Exchange for the period of 2011 to 2017 . The study employs panel regression analysis as it allows greater variability, less collinearity, higher speed of adjustment, larger sample size, considers the heterogeneity of cross-sections, a higher degree of freedom, and better efficiency compared to time-series. The study employs Breusch and Pagan Lagrangian Multiplier (LM) to decide between pooled OLS or fixed and random effect and it shows that pooled OLS is less efficient compared to fixed and random effect models. Finally, Hausman test is applied to check the suitably of fixed or random effect for this dataset.

To investigate the influence of corporate governance on cash holding, the following regression model is employed.

$$
\mathrm{CASH}_{i_{t}}=\beta_{o}+\beta_{1} M D I R_{i t}+\beta_{2} B G E N+\varepsilon_{i t}
$$

We have applied pooled OLS regression, fixed effects regression and random effects regression for the equation above. The dependent variable is $C A S H$, measured by the ratio of cash and cash equivalent over net assets. Net assets are total assets minus cash and cash equivalent. BGEN = A binary measurement equal to one where a female is board member of firm and 0 otherwise. MDIR = Board multiple directorships calculated as a dummy variable equal 1 if the board's members individually hold two or more directorships and 0 otherwise. Finally, $\alpha$ is the error term. The index $i$ and $t$ are the company $i$ and year $t$, respectively.

Table 1. Descriptive Analysis.

\begin{tabular}{lllllll}
\hline variable & Obs. & Min & Max & Mean & Std.D & Prob. \\
\hline CASH & 609 & 0.0009 & 0.3833 & 0.06965 & 0.0986 & 0.0271 \\
BGEN & 609 & 0.0000 & 1.0000 & .216748 & .41236 & 0.0000 \\
MDIR & 609 & 0.0000 & 1.0000 & .617405 & .48642 & 1.0000 \\
\hline
\end{tabular}

$\mathrm{CASH}=$ cash holding, $\mathrm{MDIR}=$ multiple directorship, $\mathrm{BGEN}=$ board gender

\section{Results and Discussion}

Multicollinearity in the panel data may raise certain issues. Hence, correlation analysis is used to check for the possibility of multicollinearity and Table 1 shows the results. The correlation table shows that cash holdings is positively correlated with audit fee, audit firm size, institutional ownership and negatively correlated with family ownership and managerial ownership. However, none of the correlation coefficient value is greater than 0.8 , hence, it can be assumed that multicollinearity is not an issue in the dataset.

Table 2. Correlation Analysis.

\begin{tabular}{llll}
\hline & CASH & BGEN & MDIR \\
\hline CASH & 1.0000 & & \\
BGEN & 0.2838 & 1.0000 & \\
MDIR & 0.1246 & $0.0943^{*}$ & 1.0000 \\
\hline
\end{tabular}

$*$ denote statistical significance at $5 \%$ level. $\mathrm{CASH}=$ cash holding, $\mathrm{MDIR}=$ multiple directorship, BGEN = board gender

Table 2 shows the results of panel data analysis for FEM, REM, and OLS models. Based on REM, the results of hypotheses showed a positive relationship between board gender, multiple directorship and cash holdings. However, these relationships are significant.

Table 3. Regression Results.

\begin{tabular}{lllllll}
\hline & FEM & \multicolumn{3}{l}{ REM } & \multicolumn{3}{l}{ OLS } \\
\hline CASH & Coef. & P $>$ T & Coef. & P $>$ T & Coef. & P $>$ T \\
\hline BGEN & .0298855 & 0.026 & .03702 & 0.001 & .052262 & 0.000 \\
MDIR & .0209447 & 0.149 & .0190047 & 0.095 & .015443 & 0.055 \\
cons & .0502393 & 0.000 & .0498907 & 0.000 & .048785 & 0.000 \\
& $\mathrm{~F}=10.86$ & & & & $\mathrm{~F}=18.21$ \\
Model & Prob $>\mathrm{F}=0.0000$ & & & Prob $>\mathrm{F}=0.0000$ \\
Summary & $\mathrm{R}^{2}=0.0136$ & & & \multicolumn{3}{l}{$\mathrm{R}^{2}=0.0567$} \\
& Adj. $\mathrm{R}^{2}=0.0508$ & & & Adj. $\mathrm{R}^{2}=0.0536$ \\
\hline
\end{tabular}

This study finds the significant and positive relationship between board gender and cash holdings. This result is in accordance to agency theory that presence of female in the board structure can enhance their monitory efficiency. 
Previous studies found that presence of females in the board positively influence the firm performance [47, 48] increase the investors' confidence [49] and hold more cash [23]. This study found $21.67 \%$ of female representation in Jordanian firms which could be cause of decreased cash holdings. The European Bank for Reconstruction and Development have also highlighted the lower representation of females in the board structure of Jordanian firms. Moreover, this percentage is very low compared to other developing countries such as $47.92 \%$ in Malaysia [50] and $37 \%$ in Tunisia [51]. The findings of this study suggest the firms to increase the females in board to improve the cash holdings.

This study finds the significant and positive relationship between multiple directorship and cash holdings. This result is in contrast to the expectations. Multiple directorships increase the directors' expertise [39]. In other words, directors can become overcommitted and may appear unable to take effective decisions [41]. Thus, it is more likely that higher multiple directorship can be associated with high cash. This result is in support of [33] who find that high multiple directorships significantly and positively influence the cash levels.

\section{Conclusion}

This study addresses the problem that arises on the poor cash holdings management of Jordanian firms that reveled the role of board gender and multiple directorship has to play in the organization and to improve the cash holding levels. Auditor play imperative parts in the financial decisions taken by firms. The board gender, multiple directorship have positive effect on cash holdings. This study has employed panel data methodology and pre-test estimations are carried out to select the most appropriate mode. The table 2 shows the outcome of panel data analysis for the dependent variable (cash holdings). The results in the above table demonstrate the outcomes for FEM, REM and OLS. Based on Hypotheses 1 and 2, the relationship between board gender, multiple directorship and cash holdings is positive. However, results remain significant.

\section{References}

[1] Bates, T. W., Kahle, K. M., \& Stulz, R. M. (2009). Why do US firms hold so much more cash than they used to? The Journal of Finance, 64 (5), 1985-2021.

[2] Ozkan, A., \& Ozkan, N. (2004). Corporate cash holdings: An empirical investigation of UK companies. Journal of Banking \& Finance, 28 (9), 2103-2134.

[3] Uyar, A., \& Kuzey, C. (2014). Determinants of corporate cash holdings: evidence from the emerging market of Turkey. Applied Economics, 46 (9), 1035-1048.

[4] García-Teruel, P. J., \& Martínez-Solano, P. (2008). On the determinants of SME cash holdings: Evidence from Spain. Journal of Business Finance \& Accounting, 35 (1-2), 127-149.

[5] Maheshwari, Y., \& Rao, K. V. (2017). Determinants of
Corporate Cash Holdings. Global Business Review, 18 (2), 112.

[6] Dittmar, A., Mahrt-Smith, J., \& Servaes, H. (2003). International corporate governance and corporate cash holdings. Journal of financial and quantitative analysis, 38 (01), 111-133.

[7] Garcia-Appendini, E., \& Montoriol-Garriga, J. (2013). Firms as liquidity providers: Evidence from the 2007-2008 financial crisis. Journal of Financial Economics, 109 (1), 272-291.

[8] Chen, N. (2012). Corporate Thrift And Economic Growth: A Comparative Study Of Developing And Developed Countries. Journal of International Development, 24 (2), 167-184.

[9] Gill, A., \& Shah, C. (2012). Determinants of corporate cash holdings: Evidence from Canada. International Journal of Economics and Finance, 4 (1), 70.

[10] Gill, A. S., \& Biger, N. (2013). The impact of corporate governance on working capital management efficiency of American manufacturing firms. Managerial Finance, 39 (2), 116-132.

[11] PWC. (2017). Presure in the system: Unlocking enterprise value through working capital management. Retrieved from UK.

[12] ASE. (2017). Amman Stock Exchange. http://www.ammanstockex.com.jo.

[13] Shubita, M. F. (2013). Working capital management and profitability: a case of industrial Jordanian companies. International Journal of Business and Social Science, 4 (8), 108-115.

[14] Jensen, M. C., \& Meckling, W. H. (1976). Theory of the firm: Managerial behavior, agency costs and ownership structure. Journal of Financial Economics, 3 (4), 305-360.

[15] Harford, J., Mansi, S. A., \& Maxwell, W. F. (2008). Corporate governance and firm cash holdings in the US. Journal of Financial Economics, 87, 535-555.

[16] Abed, S., Al-Attar, A., \& Suwaidan, M. (2012). Corporate governance and earnings management: Jordanian evidence. International Business Research, 5 (1), 216.

[17] Iskandar, T. M., Rahmat, M. M., Noor, N. M., Saleh, N. M., \& Ali, M. J. (2011). Corporate governance and going concern problems: evidence from Malaysia. International Journal of Corporate Governance, 2 (2), 119-139.

[18] EBRD. (2016). Corporate governance in transition economies Jordan country report. In G. P. Cigna \& A. Sigheartau (Eds.): European Bank for reconstruction and development.

[19] Carter, D. A., Simkins, B. J., \& Simpson, W. G. (2003). Corporate governance, board diversity, and firm value. Financial review, 38 (1), 33-53.

[20] Byoun, S., Chang, K., \& Kim, Y. S. (2016). Does corporate board diversity affect corporate payout policy?. Asia-Pacific Journal of Financial Studies, 45 (1), 48-101.

[21] Croson, R., \& Gneezy, U. (2009). Gender differences in preferences. Journal of Economic literature, 47 (2), 448-74.

[22] Faccio, M., \& Lang, L. H. (2002). The ultimate ownership of Western European Journal of Financial Economics, 65 (3), 365-395. 
[23] Huang, J., \& Kisgen, D. J. (2013). Gender and corporate finance: Are male executives overconfident relative to female executives?. Journal of Financial Economics, 108 (3), 822839.

[24] Van Uytbergen, S., \& Schoubben, F. (2015). The effect of gender diversity on corporate cash policy. In Annual conference EUROPEAN FINANCIAL MANAGEMENT, Date: 2015/06/24-2015/06/27, Location: Amsterdam, The Netherlands.

[25] Adams, R. B., \& Ferreira, D. (2009). Women in the boardroom and their impact on governance and performance. Journal of financial economics, 94 (2), 291-309.

[26] Campbell, K., \& Mínguez-Vera, A. (2008). Gender diversity in the boardroom and firm financial performance. Journal of business ethics, 83 (3), 435-451.

[27] Council, F. R. (2016). The UK corporate governance code. London: Financial Reporting Council.

[28] IFC. (2015). Gender diversity in jordan. Research on the impact of gender diversity on the economic performance of companies in Jordan. USA: International Finance Corporation, World Bank.

[29] Jensen, M. C. (1986). Agency costs of free cash flow, corporate finance, and takeovers. The American Economic Review, 76 (2), 323-329.

[30] Harford, J. (1999). Corporate cash reserves and acquisitions. The Journal of Finance, 54 (6), 1969-1997.

[31] Opler, T., Pinkowitz, L., Stulz, R., \& Williamson, R. (1999). The determinants and implications of corporate cash holdings. Journal of Financial Economics, 52 (1), 3-46.

[32] Schoubben, F., \& Van Uytbergen, S. (2014). The effect of gender diversity on corporate cash policy.

[33] Chou, T. K., Chen, J. C., \& Hwang, T. C. (2014). Multiple directorships and value of cash. Paper presented at the 24th conference on the theories and practices of securities and financial markets, Taiwan.

[34] Bacon, J., \& Brown, J. (1974). Corporate directorship practices: Role, selection and legal status of the board. A joint Research Report from the Conference Board and the American Society of Corporate Secretaries. New York.

[35] Booth, J. R., \& Deli, D. N. (1996). Factors affecting the number of outside directorships held by CEOs. Journal of Financial Economics, 40 (1), 81-104.

[36] Zahra, S. A., \& Pearce, J. A. (1989). Boards of directors and corporate financial performance: A review and integrative model. Journal of Management, 15 (2), 291-334.

[37] Pfeffer, J., \& Salancik, G. (1978). The external control of organizations: A resource dependence perspective. New York: Harper and Row.
[38] Fama, E. F., \& Jensen, M. C. (1983). Separation of ownership and control. The Journal of Law and Economics, 26 (2), 301325 .

[39] Carpenter, M. A., \& Westphal, J. D. (2001). The strategic context of external network ties: Examining the impact of director appointments on board involvement in strategic decision making. Academy of Management journal, 44 (4), 639-660.

[40] Ferris, S. P., Jagannathan, M., \& Pritchard, A. C. (2003). Too busy to mind the business? Monitoring by directors with multiple board appointments. The Journal of finance, 58 (3), 1087-1111.

[41] Fich, E. M., \& Shivdasani, A. (2006). Are busy boards effective monitors? The Journal of Finance, 61 (2), 689-724.

[42] Perry, T., \& Peyer, U. (2005). Board seat accumulation by executives: A shareholder's perspective. The Journal of Finance, 60 (4), 2083-2123.

[43] Ahn, S., Jiraporn, P., \& Kim, Y. S. (2010). Multiple directorships and acquirer returns. Journal of Banking \& Finance, 34 (9), 2011-2026.

[44] Masulis, R. W., \& Mobbs, S. (2011). Are all inside directors the same? Evidence from the external directorship market. the Journal of Finance, 66 (3), 823-872.

[45] Jiraporn, P., Singh, M., \& Lee, C. I. (2009). Ineffective corporate governance: Director busyness and board committee memberships. Journal of Banking \& Finance, 33 (5), 819-828.

[46] Jaafar, A., \& El-Shawa, M. (2009). Ownership concentration, board characteristics and performance: evidence from Jordan. In Accounting in Emerging Economies (pp. 73-95). Emerald Group Publishing Limited.

[47] Farrell, K. A., \& Hersch, P. L. (2005). Additions to corporate boards: the effect of gender. Journal of Corporate finance, 11 (1-2), 85-106.

[48] Khan, W. A., \& Vieito, J. P. (2013). CEO gender and firm performance. Journal of Economics and Business, 67, 55-66.

[49] Kang, E., Ding, D. K., \& Charoenwong, C. (2010). Investor reaction to women directors. Journal of Business Research, 63(8), 888-894.

[50] Alquhaif, A. S., Latif, R. A., \& Chandren, S. (2017). Employee stock options and real earnings management through accretive share buyback in Malaysia. Journal of Advanced Research in Business and Management Studies, 1 (1), 76-84.

[51] Loukil, N., \& Yousfi, O. (2016). Does gender diversity on corporate boards increase risk-taking?. Canadian Journal of Administrative Sciences/Revue Canadienne des Sciences de l'Administration, 33 (1), 66-81. 